\title{
Lembranças de Florestan
}

FRANCISCO WEFFORT

S

ENHOR REITOR, professor Flávio Fava de Moraes, senhor Secretário de Cultura do Estado de São Paulo, Marcos Mendonça, e como temos muitos professores na mesa e muitos mais no plenário, eu queria mencionar o nome do professor Antonio Candido e homenagear em seu nome todos os professores e professoras presentes.

Tenho lembranças de Florestan como aluno e é apenas dessas lembranças que falo. O meu período como estudante de graduação na Faculdade de Filosofia e os contatos que tive, como aluno, com Florestan, deixaram para mim a lembrança de uma figura fortíssima, entre muitas outras que outros possam ter tido a respeito dele. Evidentemente Florestan, grande homem que foi, e que continua sendo para todos nós, permite interpretações diversas a respeito de seu percurso. A minha visão de Florestan é a de quem foi seu aluno na universidade, e é dessa que eu quero falar.

O primeiro traço que eu mencionaria, perdoem-me se sou demasiado óbvio para alguns, é o de fundador da Sociologia moderna no Brasil. Sei que a fundação da Sociologia no Brasil é um processo muito complexo, do ponto de vista intelectual e não quero retraçar e nem poderia fazê-lo nestas circunstâncias. Da minha experiência, a experiência da minha formação intelectual, o modo pelo qual a Sociologia se apresenta como ciência é através, embora não exclusivamente, mas sobretudo, do conhecimento de Florestan Fernandes. A Sociologia, como todos sabem, não é a única das ciências sociais, e a minha trajetória pessoal na Faculdade de Filosofia esteve sempre muito mais ligada à velha cátedra de Política e ao nome de Lourival Gomes Machado, mas o padrão da ciência social vinha através de Florestan.

Sempre falo de um período de seu trabalho, mas é o período que tocou a mim viver como seu aluno. Eu me lembro de alguns textos seus sobre métodos nas ciências sociais que li uma vez, duas vezes, três vezes, como muitos de seus alunos, aprendendo nas sucessivas leituras um estilo de pensamento, uma maneira de entender a realidade social. Acho que Florestan é certamente a figura mais importante no processo de fundação da Sociologia moderna no Brasil. Ele criou, formou discípulos, e esses discípulos se tornaram mestres e formaram outros e a presença de Florestan, hoje, é um fenômeno que vai além da interpretação que já se deu da sua obra. Interpretação ampla e que fala de uma Escola Paulista de Sociologia. A meu ver é muito mais do que isso. A presença de Florestan na 
Sociologia é hoje um fenômeno nacional e certamente passa através da presença de alguns de seus discípulos, pelo menos na América Latina, para outros países latino-americanos. Esse é o primeiro Florestan Fernandes do qual gostaria de me lembrar nesta oportunidade.

O segundo Florestan, entre os muitos que são possíveis na nossa lembrança, é o do militante da educação, é o do militante da escola pública. Entendo que nos debates dos anos 60 sobre educação no Brasil se formou uma parte do que veio a ser o pensamento democrático brasileiro. Não apenas dos anos 60 , mas dos anos que se seguiram. E Florestan é herdeiro de uma tradição forte nessa linha, cujo fundador, ou um dos fundadores, Fernando de Azevedo, aparece nos anos 60 para mim e para muitos de seus estudantes como defensor de uma escola pública que não era só a universidade, nem só a Faculdade de Filosofia, mas todo o sistema da escola pública nacional, prenunciando o sacrificio que a escola pública, como sistema, haveria de sofrer de meados dos anos $60 \mathrm{em}$ diante. Entendo que na obra de militante intelectual, e falo sobretudo desse período dos combates pela escola pública, está um Florestan político, extremamente presente e importante na formação de seus estudantes, pelo menos de alguns deles entre os quais me incluo, porque ofereceu essa passagem da Sociologia para o processo educacional em visão política de caráter mais amplo.

O terceiro Florestan Fernandes que menciono é o ativamente político. É o Florestan do engajamento partidário, do engajamento na luta política da rua, no engajamento da luta eleitoral. É um outro tipo de luta política, não é a mesma coisa que uma campanha da escola pública. É o Florestan que vai ao Congresso Nacional e à Constituinte e que tenta ter influência e certamente tem, uma importante influência política sobre tendências do pensamento político militante da esquerda brasileira. E uma presença extremamente forte de um pensamento de esquerda que nele talvez tenha tido uma das suas expressões mais rigorosas que a esquerda brasileira alcançou definir naquele momento. Assim como o processo de formação da Sociologia é complexo, talvez mais complexo ainda seja o do desenvolvimento do pensamento na esquerda. Não me seria permitido, nem eu desejaria tratar disso aqui, mas creio que se pode e se deve reconhecer nesta terceira imagem de Florestan Fernandes uma presença da militância política, que talvez não lhe tivesse sido possível sem a experiência na Sociologia, sem a experiência educacional. Falo de três Florestan Fernandes, na verdade falo de um só, porque acredito que este homem terá sido talvez a visão mais íntegra que um ser humano pode oferecer a outros nas circunstâncias de quem viveu nos seus combates e na sua vida.

Francisco Weffort, sociólogo, é ministro da Cultura do Brasil.

Discurso feito pelo autor no Ato Presenf̧a de Florestan Fernandes, realizado pelo IEA na Sala do Conselho Universitário da USP em 5 de outubro de 1995. 